University of Nebraska - Lincoln

DigitalCommons@University of Nebraska - Lincoln

USDA National Wildlife Research Center - Staff Publications
U.S. Department of Agriculture: Animal and Plant Health Inspection Service

2015

\title{
Non-target species mortality and the measurement of brodifacoum rodenticide residues after a rat (Rattus rattus) eradication on Palmyra Atoll, tropical Pacific
}

\author{
William C. Pitt \\ USDA APHIS, Wildlife Services, National Wildlife Research Center, Hawaii Field Station, Hilo, HI \\ Are R. Berentsen \\ USDA APHIS, Wildlife Services, National Wildlife Research Center, Fort Collins, CO \\ Aaron B. Shiels \\ USDA APHIS, Wildlife Services, National Wildlife Research Center, Hawaii Field Station, \\ aaron.b.shiels@aphis.usda.gov \\ Steven F. Volker \\ USDA APHIS, Wildlife Services, National Wildlife Research Center, Fort Collins, CO \\ John D. Eisemann \\ USDA/APHIS/WS National Wildlife Research Center, John.D.Eisemann@aphis.usda.gov

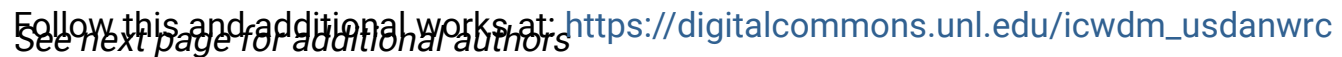 \\ Part of the Life Sciences Commons
}

Pitt, William C.; Berentsen, Are R.; Shiels, Aaron B.; Volker, Steven F.; Eisemann, John D.; Wegmann, Alexander S.; and Howald, Gregg R., "Non-target species mortality and the measurement of brodifacoum rodenticide residues after a rat (Rattus rattus) eradication on Palmyra Atoll, tropical Pacific" (2015). USDA National Wildlife Research Center - Staff Publications. 1713.

https://digitalcommons.unl.edu/icwdm_usdanwrc/1713

This Article is brought to you for free and open access by the U.S. Department of Agriculture: Animal and Plant Health Inspection Service at DigitalCommons@University of Nebraska - Lincoln. It has been accepted for inclusion in USDA National Wildlife Research Center - Staff Publications by an authorized administrator of DigitalCommons@University of Nebraska - Lincoln. 


\section{Authors}

William C. Pitt, Are R. Berentsen, Aaron B. Shiels, Steven F. Volker, John D. Eisemann, Alexander S.

Wegmann, and Gregg R. Howald 
Special Issue Article: Tropical rat eradication

\title{
Non-target species mortality and the measurement of brodifacoum rodenticide residues after a rat (Rattus rattus) eradication on Palmyra Atoll, tropical Pacific
}

\author{
William C. Pitt ${ }^{\mathrm{a}, *}$, Are R. Berentsen ${ }^{\mathrm{b}}$, Aaron B. Shiels ${ }^{\mathrm{a}}$, Steven F. Volker ${ }^{\mathrm{b}}$, John D. Eisemann ${ }^{\mathrm{b}}$, \\ Alexander S. Wegmann ${ }^{\mathrm{c}}$, Gregg R. Howald ${ }^{\mathrm{d}}$ \\ ${ }^{a}$ USDA APHIS, Wildlife Services, National Wildlife Research Center, Hawaii Field Station, Hilo, HI 96720, United States \\ ${ }^{\mathrm{b}}$ USDA APHIS, Wildlife Services, National Wildlife Research Center, 4101 LaPorte Avenue, Fort Collins, CO 80521, United States \\ ${ }^{\mathrm{c}}$ Island Conservation - Hawaii Program Office, Pacific Reefs National Wildlife Refuge Complex, 300 Ala Moana Blvd. Rm 5-231, Honolulu, HI 96850, United States \\ ${ }^{\mathrm{d}}$ Island Conservation, 400-163 West Hastings Street, Vancouver, BC V6B 1H5, Canada
}

\section{A R T I C L E I N F O}

\section{Article history:}

Received 5 June 2014

Received in revised form 15 December 2014

Accepted 8 January 2015

Available online 3 February 2015

\section{Keywords:}

Aerial broadcast

Brodifacoum rodenticide

Invasive rodent eradication

Toxicant residue

Trophic level bioaccumulation

Tropical island forest

\begin{abstract}
A B S T R A C T
The use of rodenticides to control or eradicate invasive rats (Rattus spp.) for conservation purposes has rapidly grown in the past decades, especially on islands. The non-target consequences and the fate of toxicant residue from such rodent eradication operations have not been well explored. In a cooperative effort, we monitored the application of a rodenticide, 'Brodifacoum 25W: Conservation', during an attempt to eradicate Rattus rattus from Palmyra Atoll. In 2011, Brodifacoum 25W: Conservation was aerially broadcasted twice over the entire atoll $\left(2.5 \mathrm{~km}^{2}\right)$ at rates of $80 \mathrm{~kg} / \mathrm{ha}$ and $75 \mathrm{~kg} / \mathrm{ha}$ and a supplemental hand broadcast application $(71.6 \mathrm{~kg} / \mathrm{ha}$ ) occurred three weeks after the second aerial application over a 10 ha area. We documented brodifacoum residues in soil, water, and biota, and documented mortality of non-target organisms. Some bait (14-19\% of the target application rate) entered the marine environment to distances $7 \mathrm{~m}$ from the shore. After the application commenced, carcasses of 84 animals representing 15 species of birds, fish, reptiles and invertebrates were collected opportunistically as potential non-target mortalities. In addition, fish, reptiles, and invertebrates were systematically collected for residue analysis. Brodifacoum residues were detected in most (84.3\%) of the animal samples analyzed. Although detection of residues in samples was anticipated, the extent and concentrations in many parts of the food web were greater than expected. Risk assessments should carefully consider application rates and entire food webs prior to operations using rodenticides.
\end{abstract}

Published by Elsevier Ltd.

\section{Introduction}

Island biotas are well known to suffer from negative effects of invasive (non-native) species, such as rodents (Angel et al., 2009; Shiels et al., 2014; Towns et al., 2006). Rodent eradication entails removal of all rodents from an area over a short period and then maintaining the area as rodent free using quarantine methods. Technological advances such as aerial broadcast of rodenticides

* Corresponding author at: Smithsonian Conservation Biology Institute, National Zoological Park, 1500 Remount Road, Front Royal, VA 22630, United States. Tel.: +1 5406356510

E-mail addresses: PittW@SI.edu (W.C. Pitt), Are.R.Berentsen@aphis.usda.gov (A.R. Berentsen), Aaron.B.Shiels@aphis.usda.gov (A.B. Shiels), Steven.F.Volker@ aphis.usda.gov (S.F. Volker), John.D.Eisemann@aphis.usda.gov (J.D. Eisemann), Alex.Wegmann@islandconservation.org (A. Wegmann), Gregg.Howald@ islandconservation.org (G. Howald). over the past few decades have enabled increasingly large islands to be targeted for rodent eradication (Howald et al., 2007). Since rodent eradication programs began on small islands in the early 1960 s, rats have been removed from over 450 islands around the world (Howald et al., 2007; Towns, 2009; Witmer et al., 2011). However, a major challenge that remains in invasive species eradication programs that use toxicants is to balance successfully applying enough toxicant to remove the invasive species while minimizing environmental pollution and avoiding non-target mortalities.

The black rat, Rattus rattus L. has been identified as the most damaging invasive rodent species to island ecosystems (Banks and Hughes, 2012; Ruffino et al., 2009; Shiels et al., 2014; Traveset et al., 2009). Much of the ecosystem damage attributable to $R$. rattus arises from a highly omnivorous diet that largely includes fruits and seeds (Fall et al., 1971; Clark, 1981; 
Grant-Hoffman and Barbosa, 2010; Shiels and Drake, 2011; Sweetapple and Nugent, 2007), as well as invertebrates and vertebrates (Caut et al., 2008; St Clair, 2011; Shiels et al., 2013). This commensal rodent is widespread, occurring on all continents except Antarctica, and on most islands between $55^{\circ} \mathrm{N}$ and S latitudes (Shiels et al., 2014). Globally, $R$. rattus is associated with the greatest number of declines or extinctions of native island biota (Towns et al., 2006). Therefore, efforts to reduce and eradicate $R$. rattus from conservation areas have grown exponentially over the past 30 years (Howald et al., 2007).

The most common rodenticides used for conservation of native species and habitats, such as brodifacoum, contain anticoagulants. These anticoagulants are generally mixed into a bait matrix that contains cereal or other foods that are commonly desired by rodents. Baits that contain anticoagulants typically require multiple feedings by each individual rat, yet brodifacoum is more toxic than others and typically requires fewer feedings for a lethal dose (Parkes et al., 2011). Using efficacy and palatability trials that included nine commercial rodenticide bait formulations, Pitt et al. (2011) found that second-generation anticoagulants, such as brodifacoum, generally had the highest efficacy on $R$. rattus. Non-target effects are of concern with anticoagulants, and all vertebrates are potentially susceptible to the negative effects of brodifacoum when consumed directly (primary exposure) or indirectly (e.g., via predation or scavenging of organisms containing the anticoagulants, i.e. secondary exposure). A number of studies have analyzed non-target species for anticoagulant residues following rodenticide operations that are conducted for biological conservation purposes (e.g., Dowding et al., 1999; Dunlevy and Swift, 2010; Howald et al., 1999, 2009; Masuda et al., 2014; Ogilvie et al., 1997; Pitt et al., 2005). Furthermore, residues from brodifacoum can move through the local food web and persist in the environment for unknown periods (e.g., Dowding et al., 2006; Ebbert and Burek-Huntington, 2010; Primus et al., 2005). Clearly the need is great to understand the environmental and non-target effects from rodenticide use for conservation purposes.

In this study, we (1) document the brodifacoum residues, or lack thereof, in soil, water, and biota from a rat eradication on Palmyra Atoll (hereafter "Palmyra"), tropical Pacific, (2) document short-term (3 month) non-target mortality to Palmyra's biota caused by the bait application, (3) identify pathways for which non-target species could be exposed to rodenticide residues, and (4) compare brodifacoum exposure levels of target and non-target species at Palmyra to other similar studies that employed rodenticides. A much higher application rate of brodifacoum bait was applied to Palmyra than for any other previous rat eradication projects to date, thus we expected that the number of non-target mortalities would be higher than projects where less rodenticide was applied. We also expected that brodifacoum residues would be at higher concentrations within the food web at Palmyra than in other rat eradication studies that had used lower application rates of anticoagulant rodenticides.

\section{Materials and methods}

\subsection{Study site}

This study took place at Palmyra Atoll National Wildlife Refuge (Palmyra; $5^{\circ} 53^{\prime} \mathrm{N}, 162^{\circ} 05^{\prime} \mathrm{W}$ ) which is an isolated atoll approximately $1600 \mathrm{~km}$ south of Honolulu, Hawaii, in the Northern Line Islands. Palmyra consists of 25 low (maximum elevation $1.8 \mathrm{~m}$ ) coral islands (emergent land $=232 \mathrm{ha}$ ). It is co-owned and managed by the U.S. Fish and Wildlife Service (USFWS) and The Nature Conservancy (TNC) to protect, restore, and enhance migratory birds, coral reefs, and threatened and endangered species. The majority of the vegetation is categorized as moist forest (Wester, 1985), dominated by Cocos nucifera (Arecaceae), Scaevola taccada (Goodeniaceae), and Tournefortia argentea (Boraginaceae), as well as patchy stands of Pisonia grandis (Nyctaginaceae), Pandanus fischerianus (Pandanaceae), Hibiscus tiliaceus (Malvaceae), and Terminalia catappa (Combretaceae). Average annual rainfall is approximately $4.4 \mathrm{~m}$, and mean daily air temperature is $29^{\circ} \mathrm{C}$.

$R$. rattus is the only terrestrial mammal on Palmyra, and it was probably unintentionally introduced during military operations during and after WWII. There is a rich diversity of land crabs on Palmyra, including hermit crabs (Coenobita perlatus and Coenobita brevimanus; Coenobitidae), the coconut crab (Birgus latro; Coenobitidae), additional terrestrial crabs (Cardisoma carnifex and Cardisoma rotundum; Gecarcinidae), and semi-terrestrial crabs (e.g., fiddler crabs, Uca tetragonon; Ocypodidae). Palmyra is home to a diversity of seabirds, including red-footed boobies (Sula sula) and seasonal populations of migratory birds that include two species of primary conservation concern: bristle-thighed curlews (Numenius tahitiensis), and Pacific golden plover (Pluvialis fulva).

\subsection{Bait application methodology}

The bait application operation was conducted by Island Conservation (IC), and the environmental monitoring was led by United States Department of Agriculture (USDA) and implemented by a cooperative team composed of personnel from USDA, the U.S. Geological Survey (USGS), and USFWS. There were two atoll-wide aerial applications of brodifacoum bait (12-14, 16 June, and 21-22 June, 2011) during the time when the seabird and shorebird populations were the lowest (USFWS, 2011). All emergent land areas were treated by spreading the bait as evenly as possible at a rate of $80 \mathrm{~kg} / \mathrm{ha} \mathrm{(12-16} \mathrm{June)} \mathrm{and} 75 \mathrm{~kg} / \mathrm{ha} \mathrm{(21-22} \mathrm{June)} \mathrm{with} \mathrm{the} \mathrm{goal}$ of delivering a lethal dose of rodenticide into every potential rat territory on Palmyra.

The rodenticide product used for this project was approved by the U.S. Environmental Protection Agency (EPA) as a supplemental label to the parent label Brodifacoum 25W: Conservation (EPA Reg. No. 56228-36). The time-limited supplemental label was for use only on Palmyra and allowed significant modifications to the application methods detailed in the parent label. In particular, it allowed 4 to 8 -fold increases in the broadcast application rates from the parent label. This modification was justified based on evidence of high bait competition from land crabs at Palmyra (Wegmann et al., 2012). The parent label allows two broadcast applications made at a rate of $18 \mathrm{~kg} / \mathrm{ha}$ for the first application and if needed, $9 \mathrm{~kg} / \mathrm{ha}$ for the second application. The supplemental label allowed two applications at a maximum rate of $90 \mathrm{~kg} / \mathrm{ha}$ per application. In addition, the supplemental label allowed a maximum of $47,000 \mathrm{~kg}$ of bait for the entire operation. The parent label does not specify a maximum amount per operation.

Bait was applied using techniques designed to minimize the risk of bait directly entering the marine environment. While the helicopter dispensed most bait, approximately $5 \%$ of the atoll was baited using alternative methods, including small biodegradable pouches slung into the crowns of coconut palms overhanging near-shore waters, bait stations at commensal areas, and handbaiting inside abandoned WWII-era structures (e.g., bunkers, pillboxes) and along swaths of land too narrow for accurate aerial application. A supplemental hand broadcast application $(71.6 \mathrm{~kg} /$ ha) occurred three weeks after the second aerial application over a 10 ha area containing the operation camp in response to the capture of a live rat. Variation in bait density resulting from the aerial broadcast (Engeman et al., 2013), and the longevity of bait pellets (Berentsen et al., 2014) were reported previously for this study. 


\subsection{Environmental monitoring methodology}

All soil and terrestrial biological samples were collected from the collective landmass of Cooper, Strawn and Aviation Islands (hereafter "Cooper Complex"). All references to sample collection periods begin on the day the Cooper Complex was baited (13 June 2011). Aquatic biological samples were collected from the Cooper Complex and the South Complex (Fig. 1). Soil, water, and biological monitoring began 11 days prior to the first rodenticide application and continued for eleven weeks, divided into five time periods (Table 1).

Our sampling effort was focused on abundant species, native or introduced, representative of different compartments of the island food web. Biological samples were frozen and stored at $-80{ }^{\circ} \mathrm{C}$ after collection, and soil and water samples were stored in a refrigerator. Personnel had not handled bait on days during which samples were collected. The rodenticide bait used in this operation was also sampled to determine brodifacoum levels.

Ants (primarily the non-native Pheidole megacephala; 2-6 g per pooled sample) were captured opportunistically from multiple locations on the largest island, Cooper Island, which serves as the center of operations for the Refuge, using closed Haguruma rat traps baited with fresh coconut. Traps were checked multiple times daily and ants were collected by shaking the trap over a plastic container filled with fresh water with 3-5 drops of liquid dish detergent. The water was filtered through a paper towel in a funnel and the ants were allowed to air dry. Non-native cockroaches (Periplaneta spp.; 2-6 g per pooled sample) were hand captured in terrestrial rubble piles within abandoned and occupied buildings on Cooper Island. Cockroaches were placed in plastic bags and frozen.

Two types of (native) crabs were collected: fiddler crabs $(U$. tetragonon), and strawberry hermit crabs (C. perlatus). Fiddler crabs are detritivores inhabiting open tidal mudflats which are often submerged during high tide. They were selected for collection as a representative of a scavenging intertidal species. Fiddler crabs were collected on the Cooper Complex by burrow excavation. The strawberry hermit crab, which is the most abundant species of hermit crab at Palmyra, was collected opportunistically throughout the Cooper Complex. Upon collection, conspecific crabs were placed in sample groups of five in labeled plastic bags and frozen. Once frozen, hermit crabs were extracted from their shells and returned to the freezer (shells were returned to the atoll).

The Black Spot Sergeant (Abudefduf sordidus), which is an abundant native fish inhabiting coral reefs and rubble piles at Palmyra, was captured in waters up to $1 \mathrm{~m}$ deep surrounding the Cooper Complex and the South Complex using hook and line or by spear (euthanized by pithing and decapitation). Fish were rinsed in fresh water to remove sand, grouped into one to six individuals per plastic bag (sample), and frozen.

Geckos (Lepidodactylus lugubris and Hemidactylus frenatus) (both species probably non-native) were opportunistically hand-collected after sunset from buildings and from under palm fronds on Cooper Island. Geckos were euthanized by overdose of gas anesthetic (Isofluorane) followed by pithing and decapitation, then grouped in samples of five individuals.

Focused carcass searches were performed daily along two transects frequented by shorebirds (North Beach and the Runway) beginning six days prior to the first bait drop and continued for 28 consecutive days. Carcasses were also collected opportunistically during routine shorebird censuses and during all other daily activities on the atoll for up to seven months after commencement of the first aerial application of bait. These searches focused on areas of known shorebird roosting and shorebird survey areas. All carcasses collected were placed in individually labeled plastic bags and stored in the freezer.

Water samples were collected across Palmyra at 12 sites: six shallow-water locations inside the lagoon near the shore, three deep-water locations outside the lagoon, two terrestrial standing water locations, and the fresh water catchment on Cooper Complex. Samples were collected in $1.0 \mathrm{~L}$ glass bottles that were

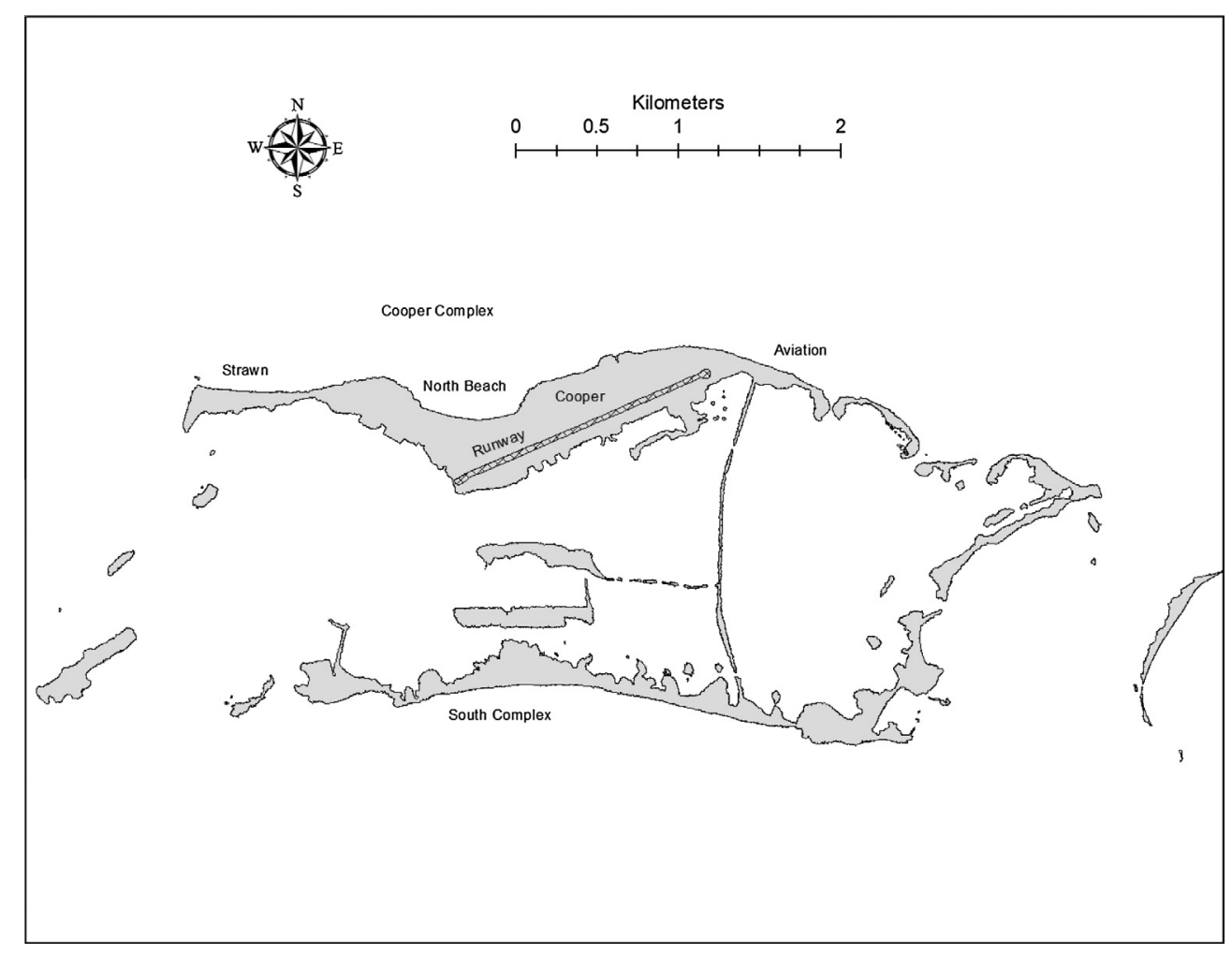

Fig. 1. Map of Palmyra showing sampling areas, 2011. 
Table 1

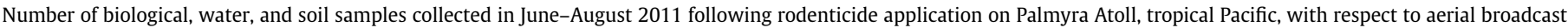

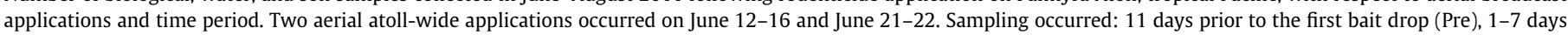

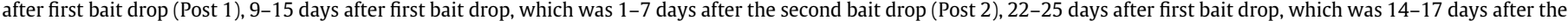
second bait drop (Post 3), and 54-60 days after the first bait drop, which was 46-52 days after the second bait drop (Post 4).

\begin{tabular}{|c|c|c|c|c|c|c|c|}
\hline & \multicolumn{7}{|l|}{ Time period } \\
\hline & \multicolumn{2}{|l|}{ Pre } & \multicolumn{2}{|l|}{ Post 1} & \multirow{2}{*}{$\begin{array}{l}\text { Post } 2 \\
23-28 \text { June }\end{array}$} & \multirow{2}{*}{$\begin{array}{l}\text { Post } 3 \\
5-8 \text { July }\end{array}$} & \multirow{2}{*}{$\begin{array}{l}\text { Post } 4 \\
6-12 \text { August }\end{array}$} \\
\hline & 2-12 June & 13 June & 14-20 June & 21-22 June* & & & \\
\hline Days since first application: & $\mathrm{N} / \mathrm{A}$ & 0 & $1-7$ & $8-9$ & $10-15$ & $22-25$ & $54-60$ \\
\hline \multicolumn{8}{|l|}{ Sample item } \\
\hline Geckos & 2 & Application 1 & 5 & Application 2 & 5 & 5 & 5 \\
\hline Fiddler crabs & 2 & & 5 & & 2 & 5 & 1 \\
\hline Hermit crabs & 2 & & 5 & & 5 & 5 & 5 \\
\hline Cockroaches & 2 & & 4 & & 5 & 5 & 2 \\
\hline Ants & 2 & & 4 & & 5 & 5 & 1 \\
\hline Fish & 10 & & $\mathrm{~N} / \mathrm{A}$ & & 10 & $\mathrm{~N} / \mathrm{A}$ & $\mathrm{N} / \mathrm{A}$ \\
\hline Salt water & 9 & & 9 & & 18 & $\mathrm{~N} / \mathrm{A}$ & $\mathrm{N} / \mathrm{A}$ \\
\hline Fresh water & 3 & & 2 & & 5 & $\mathrm{~N} / \mathrm{A}$ & $\mathrm{N} / \mathrm{A}$ \\
\hline Soil & 7 & & $\mathrm{~N} / \mathrm{A}$ & & 7 & 7 & 7 \\
\hline
\end{tabular}

* 22 June included as a sampling day as sampling began on portions of the atoll baited on 21 June and focused carcass searches were conducted daily.

chemically cleaned by the manufacturer and double bagged. Each bottle was affixed with a label immediately prior to use. During collection a bottle was held just below the water surface until full, then sealed and returned to its original storage bag.

Soil samples were collected from seven areas throughout the Cooper Complex. Samples were collected in $125 \mathrm{~mL}$ glass jars chemically cleaned by the manufacturer. Labels were affixed to each jar immediately prior to sample collection. We collected $125 \mathrm{~mL}$ of soil from the top $8-10 \mathrm{~cm}$ of the soil profile by pressing the jar directly into the soil until full.

\subsection{Sample preparation and brodifacoum laboratory analysis}

All samples were shipped on ice for brodifacoum extraction and analysis from Palmyra to the USDA National Wildlife Research Center in Colorado, U.S.A. Analysis was performed by high performance liquid chromatography (HPLC) with fluorescence detection (FLD). Difenacoum was added as the surrogate to all matrices. Quality control samples of brodifacoum-fortified control matrices were included with each analysis. Detection limits were determined for each sample type.

\subsubsection{Water}

Seawater and freshwater samples $(150 \mathrm{~mL})$ were spiked with surrogate ( $1 \mu \mathrm{g}$ difenacoum), acidified with $0.5 \%(\mathrm{v} / \mathrm{v})$ trifluoroacetic (TFA) acid $(50 \mathrm{~mL})$, and passed through Empore ${ }^{\circledR}$ C18 Solid Phase Extraction Disks conditioned with $0.5 \%$ TFA using a vacuum manifold ( $\sim 60 \mathrm{~mL} / \mathrm{min})$. Samples were eluted with $20 \mathrm{~mL}$ of $100-$ $\mathrm{mM}$ ammonium hydroxide in 1:1 chloroform:methanol and filtered through $0.45-\mu \mathrm{m}$ PTFE syringe filters. The filtrates were reduced to dryness under $\mathrm{N}_{2}$ at $60{ }^{\circ} \mathrm{C}$ and reconstituted with $600 \mu \mathrm{L}$ of $5-\mathrm{mM}$ TBAP in methanol followed by addition of $400 \mu \mathrm{L} 5$-mM TBAP in $\mathrm{pH} 8.56$-mM phosphate buffer. Each extract was transferred to $1.5-\mathrm{mL}$ capacity microcentrifuge tube and clarified by centrifugation at $15,000 \mathrm{~g}$ for $1 \mathrm{~min}$. prior to HPLC analysis.

\subsubsection{Terrestrial crabs}

The hepatopancreas and meat from the forelegs and claws were removed from land crabs, and hermit crabs were whole-body homogenized (Primus and Graves, 2006). Tissues were homogenized using a SPEX CertiPrep 6850 Liquid Nitrogen Freezer Mill (SPEX Certiprep Group, LLC, Metuchen, NJ). Samples of homogenized hermit crab whole body $(0.50 \mathrm{~g})$, and land crab meat and hepatopancreas $(1.00 \mathrm{~g})$ were placed into $50 \mathrm{~mL}$ glass tubes and spiked with $1 \mu \mathrm{g}$ of the surrogate. Each sample was extracted as described by Primus et al. (2006) with the following modification: $1 \mathrm{~mL}$ of $17 \% \mathrm{~L}$-ascorbic acid was added to hermit crab whole body and land crab meat samples prior to extraction.

\subsubsection{Soil}

Soil samples were dried for $24 \mathrm{~h}$ at $105^{\circ} \mathrm{C}$ and $1.00 \mathrm{~g}$ samples of dried soil were placed into MARSXpress 55-mL Teflon Digestion Vessels (CEM Corp, Matthews, NC). One $\mu \mathrm{g}$ of surrogate was added followed by $20 \mathrm{~mL}$ of $1.0 \%$ formic acid in 1:1 chloroform:methanol. Each sample was extracted using a Microwave Accelerated Reaction System (MARS, CEM Corp) by heating to $124^{\circ} \mathrm{C}$ over $18 \mathrm{~min}$, holding for $28 \mathrm{~min}$, followed by cooling to ambient temperature. The extracts were reduced to dryness subjected to SPE clean-up according to the method of Primus et al. (2006).

\subsubsection{Insects}

Insects (ants and cockroaches) were homogenized in a liquid nitrogen freezer mill and $0.25 \mathrm{~g}$ of homogenate was placed into $25-\mathrm{mL}$ glass tubes. Surrogate was added followed by $1 \mathrm{~mL}$ of $17 \%$ L-ascorbic acid. Approximately $10 \mathrm{~g}$ of sodium sulfate was added followed by $15 \mathrm{~mL}$ of $1.0 \%$ formic acid in $1: 1$ chloroform:acetone. Samples were extracted similarly to terrestrial crabs with the exception that cockroach samples were washed with $6.0 \mathrm{~mL}$ of 35/65 chloroform/hexanes.

\subsubsection{Rats, birds, geckos, and fish}

The whole bodies of geckos and fish were homogenized. The head, feet, tail, liver, and pelt/skin of rats and birds were removed and livers and remaining carcasses were homogenized separately. Aliquots $(0.50 \mathrm{~g})$ of each homogenized sample were placed in MARS vessels for microwave extraction. Surrogate was added followed by $8 \mathrm{~mL}$ of $0.1 \%$ TFA in acetonitrile. Each sample was microwave extracted (see preparation of soil samples) and filtered through $0.7-\mu \mathrm{m}$ glass fiber syringe filters into a glass tube. Extracts were reduced to dryness and reconstituted with 3:4 chloroform: hexanes. Extracts were cleaned-up using SPE with the addition of a $3 \mathrm{~mL}$ wash with methanol. Samples were clarified by centrifugation prior to HPLC analysis as described for water samples.

\subsubsection{Bait}

Bait pellets were homogenized using a liquid nitrogen freezer mill and $0.50 \mathrm{~g}$ aliquots were placed in MARS vessels. Surrogate was added $(35 \mu \mathrm{g})$ and $25 \mathrm{~mL}$ of a $5-\mathrm{mM}$ TBAP in $80 \%(\mathrm{pH} 8.5$ 6-mM phosphate buffer)/20\% (methanol) extraction solution was added. Each sample was microwave extracted and the 
supernatants were transferred to $25 \mathrm{~mL}$ glass tubes for clarification by centrifugation ( $1200 \mathrm{~g}$ for $5 \mathrm{~min}$.) followed by filtration with a $0.45-\mu \mathrm{m}$ syringe filter. Filtrates were delivered to 25 -mL volumetric flasks and brought to volume with extraction solution.

\subsubsection{Brodifacoum analysis}

Brodifacoum analyses were performed with Agilent 1100 and 1200 HPLC systems. Brodifacoum concentrations were determined from the peak area ratio of brodifacoum to surrogate in each extracted sample, and were compared to the average peak area ratio from replicate injections of a working standard. Samples with analytical concentrations above the linear range were re-diluted into the linear region. The HPLC parameters used for the analysis of water samples were applied to the other extracts, with minor modifications to the mobile phase gradient as needed (see Appen$\operatorname{dix}$ A).

\section{Results}

\subsection{Bait analysis results}

Results of the chemical analysis conducted on the bait used ( $n=3$ pooled samples) for the eradication showed that brodifacoum levels exceeded the certified limits for this product (40 CFR $158.175)(25 \pm 2.5 \mu \mathrm{g} / \mathrm{g}$; mean $\pm \mathrm{SE})$ by $1.4-2.2 \%$. The three analyzed samples had concentrations ranging from $27.9 \mu \mathrm{g} / \mathrm{g}(0.4 \mu \mathrm{g} / \mathrm{g}$ above the certified limit) to $28.1 \mu \mathrm{g} / \mathrm{g}(0.6 \mu \mathrm{g} / \mathrm{g}$ above the certified limit).

\subsection{Residue analysis}

All residue data are provided in Appendix B. The original chemical analysis reports also contain quality control analysis, Method Limit of Detection (MLOD: the lowest amount of analyte in a sample which can be detected by not necessarily quantitated as an exact value), Method Limit of Quantitation (MLOQ: the lowest amount of analyte in a sample which can be quantitatively determined with suitable precision and accuracy), and additional notes. These original chemical reports may be obtained from the USDA National Wildlife Research Center. When calculating mean residue values, 0.5 MLOD was used in cases where analysis resulted in a value $<$ MLOD.

\subsection{Systematic environmental samples and chemical analysis}

\subsubsection{Water and soil}

There was only one freshwater sample that had a detectable level of brodifacoum residue (Table 2). This sample contained a large amount of organic matter that impeded the extraction procedure, resulting in a low but acceptable difenacoum (positive control compound) recovery. The initial result was $<$ MLOD, but it was decided to re-extract the sample following filtration through a 55-mm Whatman 40 filter (Whatman $\mathrm{P} / \mathrm{N} 1440-055$ ) to remove excess organic matter. The second result was above the MLOQ and is reported. There was insufficient sample for a third extraction. Two salt water samples had brodifacoum concentrations that were above the MLOQ when tested initially. The samples were reextracted to verify the initial result. Both were found to be < MLOD in final testing.

Two of the seven soil samples (28.5\%) collected prior to baiting (i.e., Pre), and seven of the 21 soil samples (33.3\%) collected after bait was applied, contained detectable brodifacoum residues (Table 2). The highest residue detected in soil $(0.056 \mu \mathrm{g} / \mathrm{g})$ occurred during Post 2. Across all time periods, nine soil samples from four locations had detectable brodifacoum residues (Table 2).

\subsubsection{Ants and cockroaches}

Seventeen samples of ants and 18 samples of cockroaches were collected (Post 4 sample weights not reported). Average weight per sample for ants was $3.8 \mathrm{~g}$ (range $0.8-6.4, n=16$ ) ${ }^{1}$ and $4.1 \mathrm{~g}$ (range 2.2-6.1, $n=16$ ) for cockroaches. All ant samples collected after bait application had detectable residues of brodifacoum. The average brodifacoum residue detected in ants peaked in sampling period Post $3(0.178 \pm 0.013 \mu \mathrm{g} / \mathrm{g}$; mean $\pm \mathrm{SE})$ and declined to $0.035(n=1)$ by sampling period Post 4 (Table 3 ). However, brodifacoum residues were detected in all ant samples collected after the initial broadcast (i.e., during Post 1) through the final sampling period (i.e., Post 4), and the average residue across all post-baiting sampling periods was $0.157 \pm 0.017 \mu \mathrm{g} / \mathrm{g}$.

Brodifacoum residue levels in cockroaches were consistently the highest among the biological samples collected (Table 3). Unlike ants, residues in cockroaches peaked in sampling period Post 2 . The average residue detected in cockroaches in sampling period Post 2 was $2.29 \pm 0.316 \mu \mathrm{g} / \mathrm{g}$ (mean $\pm \mathrm{SE}$ ) and declined to $0.856 \mu \mathrm{g} / \mathrm{g}(n=1)$ in period Post 4 . After the first bait application, the mean brodifacoum residue in cockroach samples was $1.219+0.255 \mu \mathrm{g} / \mathrm{g}$ and residues were detected in all but two samples.

\subsubsection{Hermit crabs and fiddler crabs}

One hundred and ten hermit crabs were collected throughout the Cooper Complex in 22 sample units of five individuals per sample. Two samples were collected during Pre and five samples were collected during each of periods Post 1-4. During sampling periods Post 1 and Post 2, all hermit crabs sampled contained detectable residues of brodifacoum (Table 3). The average residue detected in hermit crabs peaked in sample period Post 1 at $0.273 \pm 0.056 \mu \mathrm{g} / \mathrm{g}$ (mean $\pm \mathrm{SE}$ ) and had decreased to $0.119 \pm 0.024 \mu \mathrm{g} / \mathrm{g}$ by sampling period Post 3 . Four out of 5 hermit crab samples collected during period Post 3 contained detectable residues. During Post 4 , which was almost 2 months after the first broadcast of bait, only one of five hermit crab samples had detectable residues of brodifacoum.

One hundred and ten individual fiddler crabs were collected in 17 sample units of five individuals (two samples from Pre and five samples from each of Post periods), and one sample of 25 individuals collected in Post 4. During the last sampling period, all crabs were collected as a single sample and thus could not be analyzed separately. Unlike hermit crabs which are terrestrial, the residues in the aquatic fiddler crab did not peak until Post 2 sampling (Table 3 ). The average residue detected in fiddler crabs during the Post 2 sample period was $0.125 \pm 0.041 \mu \mathrm{g} / \mathrm{g}$ (mean $\pm \mathrm{SE}$ ). Residues in fiddler crabs collected during Post 4 were below the MLOD, however, these crabs were pooled for analysis because of a sample collection error.

\subsubsection{Geckos}

One hundred and twelve individual geckos were collected, plus a partial sample from one individual. Samples were collected in 22 units of five individuals per sample plus one unit of two individuals. Brodifacoum residues in geckos peaked at a concentration of $0.067 \pm 0.032 \mu \mathrm{g} / \mathrm{g}$ (mean $\pm \mathrm{SE}$ ) in Post 2 sampling period (Table 3 ). In Post 2 and 3 sampling periods, detectable residues were reported in three out of five samples. Four of six samples analyzed in Post 4 contained detectable residues with an average concentration of $0.023 \pm 0.005 \mu \mathrm{g} / \mathrm{g}$.

\footnotetext{
1 A single sample of ants was $0.8 \mathrm{~g}$, less than the $2.0 \mathrm{~g}$ target, but was sufficient for residue analysis.
} 
Table 2

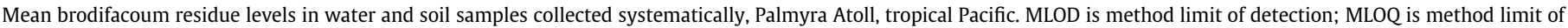
quantitation; N/A (not applicable) is listed where there was only one sample analyzed.

\begin{tabular}{|c|c|c|c|c|c|c|c|}
\hline Sample type & Sampling period & $\begin{array}{l}\text { Average residue ( } \mu \mathrm{g} / \mathrm{g} \text { for soil, } \\
\mathrm{ng} / \mathrm{ml} \text { for water) }\end{array}$ & Range & MLOD & MLOQ & \# Samples tested & \# Positive \\
\hline Soil & Pre & 0.007 & $<$ MLOD - 0.003 & $0.003 \mu \mathrm{g} / \mathrm{g}$ & $0.010 \mu \mathrm{g} / \mathrm{g}$ & 7 & 2 \\
\hline Soil & Post 2 & 0.0020 & $<$ MLOD -0.056 & & & 7 & 4 \\
\hline Soil & Post 3 & 0.014 & $<$ MLOD - 0.014 & & & 7 & 1 \\
\hline Soil & Post 4 & 0.018 & $<$ MLOD -0.021 & & & 7 & 2 \\
\hline Salt water & Pre & $<$ MLOD & $\mathrm{N} / \mathrm{A}$ & $0.011 \mathrm{ng} / \mathrm{ml}$ & $0.037 \mathrm{ng} / \mathrm{ml}$ & 9 & 0 \\
\hline Salt water & Post 1 & $<$ MLOD & $\mathrm{N} / \mathrm{A}$ & & & 9 & 0 \\
\hline Salt water & Post 2 & $<$ MLOD & $\mathrm{N} / \mathrm{A}$ & & & 18 & 0 \\
\hline Fresh water & Pre & $<$ MLOD & $\mathrm{N} / \mathrm{A}$ & $0.009 \mathrm{ng} / \mathrm{ml}$ & $0.031 \mathrm{ng} / \mathrm{ml}$ & 3 & 0 \\
\hline Fresh water & Post 1 & $<$ MLOD & $\mathrm{N} / \mathrm{A}$ & & & 2 & 0 \\
\hline Fresh water & Post 2 & 0.048 & $<$ MLOD - 0.048 & & & 5 & 1 \\
\hline
\end{tabular}

Table 3

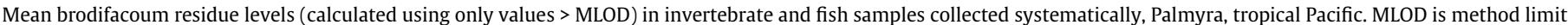
of detection; N/A (not applicable) is listed where there was only one sample analyzed.

\begin{tabular}{|c|c|c|c|c|c|c|c|}
\hline Sample type & Sampling period & Average residue $(\mu \mathrm{g} / \mathrm{g})$ & Range & MLOD $(\mu \mathrm{g} / \mathrm{g})$ & MLOQ ( $\mu \mathrm{g} / \mathrm{g})$ & \# Samples tested & \# Positive \\
\hline Fiddler crabs & Pre & $<$ MLOD & $\mathrm{N} / \mathrm{A}$ & 0.018 & 0.061 & 2 & 0 \\
\hline Fiddler crabs & Post 1 & 0.049 & $<$ MLOD - 0.06 & & & 5 & 3 \\
\hline Fiddler crabs & Post 2 & 0.125 & $<$ MLOD - 0.198 & & & 5 & 3 \\
\hline Fiddler crabs & Post 3 & 0.065 & $<$ MLOD - 0.065 & & & 5 & 1 \\
\hline Fiddler crabs & Post 4 & $<$ MLOD & $\mathrm{N} / \mathrm{A}$ & & & 1 & 0 \\
\hline Hermit crabs & Pre & $<$ MLOD & $\mathrm{N} / \mathrm{A}$ & 0.018 & 0.061 & 2 & 0 \\
\hline Hermit crabs & Post 1 & 0.273 & $0.134-0.441$ & & & 5 & 5 \\
\hline Hermit crabs & Post 2 & 0.157 & $0.053-0.356$ & & & 5 & 5 \\
\hline Hermit crabs & Post 3 & 0.119 & $<$ MLOD - 0.177 & & & 5 & 4 \\
\hline Hermit crabs & Post 4 & 0.027 & $<$ MLOD - 0.027 & & & 5 & 1 \\
\hline Cockroaches & Pre & $<$ MLOD & $\mathrm{N} / \mathrm{A}$ & 0.020 & 0.067 & 2 & 0 \\
\hline Cockroaches & Post 1 & 1.447 & $0.857-2.000$ & & & 4 & 4 \\
\hline Cockroaches & Post 2 & 2.290 & $<$ MLOD - 3.050 & & & 5 & 4 \\
\hline Cockroaches & Post 3 & 0.253 & $0.073-0.486$ & & & 5 & 5 \\
\hline Cockroaches & Post 4 & 0.856 & $<$ MLOD -0.856 & & & 2 & 1 \\
\hline Ants & Pre & $<$ MLOD & $\mathrm{N} / \mathrm{A}$ & 0.012 & 0.039 & 2 & 0 \\
\hline Ants & Post 1 & 0.161 & $0.125-0.196$ & & & 4 & 4 \\
\hline Ants & Post 2 & 0.157 & $0.069-0.304$ & & & 5 & 5 \\
\hline Ants & Post 3 & 0.178 & $0.153-0.227$ & & & 5 & 5 \\
\hline Ants & Post 4 & 0.035 & 0.035 & & & 1 & 1 \\
\hline Geckos & Pre & $<$ MLOD & $\mathrm{N} / \mathrm{A}$ & 0.011 & 0.038 & 2 & 0 \\
\hline Geckos & Post 1 & 0.012 & $<$ MLOD - 0.012 & & & 5 & 1 \\
\hline Geckos & Post 2 & 0.067 & $<$ MLOD -0.130 & & & 5 & 3 \\
\hline Geckos & Post 3 & 0.027 & $<$ MLOD - 0.042 & & & 5 & 3 \\
\hline Geckos & Post 4 & 0.023 & $<$ MLOD - 0.037 & & & 6 & 4 \\
\hline Black-spot sergeant fish & Pre & $<$ MLOD & $\mathrm{N} / \mathrm{A}$ & 0.013 & 0.042 & 10 & 0 \\
\hline Black-spot sergeant fish & Post 2 & 0.143 & $<$ MLOD - 0.315 & & & 10 & 9 \\
\hline
\end{tabular}

\subsubsection{Black-spot sergeant fish}

Eighteen samples (1-6 individuals per sample) totaling 56 individual black-spot sergeants were collected systematically around the atoll during Pre and Post 2 periods only. Eight samples consisting of 26 individuals were collected during Pre from the Cooper Complex. Ten samples consisting of 30 individuals were collected during Post 2 from the Cooper Complex and the southern shore of South Complex. No detectable brodifacoum residues were detected in black-spot sergeants collected prior to baiting, but residues were detected in black-spot sergeants that were collected during Post 2. Nine of the 10 fish samples collected during this period contained detectable residues (Table 3 ). The average residue detected was $0.143 \pm 0.027 \mu \mathrm{g} / \mathrm{g}$ (mean $\pm \mathrm{SE})$.

\subsection{Opportunistically collected biological samples and analysis}

Carcasses of 105 animals representing 16 species were collected during daily focused carcass searches along two transects frequented by shorebirds (North Beach and the Runway), and collected opportunistically during shorebird censuses and during all other daily activities on the atoll (Table 4).

\subsubsection{Birds}

After bait application, brodifacoum residues were detected in 12 of 16 individual birds that were found dead (excluding those that died from confirmed helicopter collision and one bird that died while egg-bound) in the break water or on the land (Table 5). 
Table 4

Carcasses found and collected dead on Palmyra, tropical Pacific, during June-July 2011, and the Northern pintail collected in February 2012.

\begin{tabular}{|c|c|c|}
\hline Common name & Species & $\begin{array}{l}\text { Number } \\
\text { found }\end{array}$ \\
\hline Sooty tern & Onychoprion fuscatus & $5^{a}$ \\
\hline $\begin{array}{l}\text { Bristle-thighed } \\
\text { curlew }\end{array}$ & Numenius tahitiensis & $6^{\mathrm{b}}$ \\
\hline $\begin{array}{l}\text { Pacific golden } \\
\text { plover }\end{array}$ & Pluvialis fulva & 2 \\
\hline Red-footed booby & Sula sula & $6^{c}$ \\
\hline Black noddy & Anous minutus & $1^{\mathrm{d}}$ \\
\hline Ruddy turnstone & Arenaria interpus & 2 \\
\hline Wandering tattler & Tringa incana & 1 \\
\hline Land crab & Cardisoma spp. & 7 \\
\hline Hermit crab & Coenobita perlatus & 2 \\
\hline Mullet & $\begin{array}{l}\text { Moolgarda engeli and Liza vaigiensis: } \\
\text { pooled samples }\end{array}$ & $47^{\mathrm{e}}$ \\
\hline Fiddler crab & Uca tetragonon & 1 \\
\hline Green sea turtle & Chelonia mydas & 1 \\
\hline Puffer fish & Unknown species & 1 \\
\hline Jellyfish & Unknown species & 1 \\
\hline Northern pintail & Anas acuta & $1^{\mathrm{f}}$ \\
\hline Black Rat & Rattus rattus & 21 \\
\hline
\end{tabular}

a Three birds died as a result of confirmed helicopter collisions.

b One bird died from hemorrhaging while under veterinary care.

c Four birds died as a result of confirmed helicopter collisions, one died while egg-bound.

${ }^{\mathrm{d}}$ Physical examination suggested this bird died of starvation (J. Breeden, USFWS pers. comm).

e A total of 47 individual mullets were found in 24 samples. Multiple mullets found at a single location were pooled into a single sample. Twenty-four samples containing 47 mullets were analyzed.

${ }^{\mathrm{f}}$ Found dead in February 2012. Examination suggested that the bird died of starvation (J. Breeden, USFWS pers. comm).
All bristle-thighed curlews, Pacific golden plovers, ruddy turnstones, the wandering tattler, and the Northern pintail collected had detectable brodifacoum residues. Brodifacoum residues in liver samples from all birds, where liver was available for testing, were higher than respective samples from the entire carcass. The bristle-thighed curlews had the highest average brodifacoum residues (carcass $0.78 \pm 0.098 \mu \mathrm{g} / \mathrm{g}$; liver $4.305 \pm 2.113 \mu \mathrm{g} / \mathrm{g}$ ) relative to the other birds analyzed. Brodifacoum residues were detected in the liver $(0.063 \mu \mathrm{g} / \mathrm{g})$ and the carcass $(0.007 \mu \mathrm{g} / \mathrm{g})$ of the Northern pintail collected more than 7 months after the first aerial application. However, the residue value from the Northern pintail was less than the MLOQ value for the sample. Residue concentrations above the MLOD but less than the MLOQ indicate the presence of brodifacoum, but the exact concentrations cannot be determined with certainty.

\subsubsection{Fish}

Brodifacoum residues were detected in all fish samples that were found dead and collected opportunistically after the bait application. Mullet were identified as one of two species: "kanda" (Moolgarda engeli) or "square-tailed mullet" (Liza vaigiensis). The average residue in the 24 mullet samples was $0.337 \pm 0.067 \mu \mathrm{g} / \mathrm{g}$ (mean \pm SE) and residues declined over time with the highest residues recorded in the earliest recovered samples $\left(r^{2}=0.26\right.$, Appendix B Table B12). The only other fish recovered was a puffer fish and analysis showed brodifacoum residues of $0.438 \mu \mathrm{g} / \mathrm{g}$.

\subsubsection{Cardisoma crabs}

Seven dead land crabs (Cardisoma spp.) were collected and six of them had detectable brodifacoum residues in the hepatopancreas, claw meat, or both (Table 4 and 5). Land crabs tended to have higher brodifacoum residues than either the fiddler or hermit

Table 5

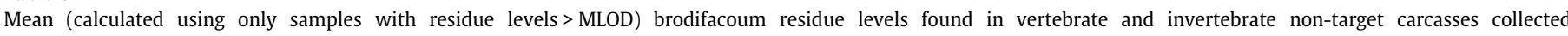
opportunistically, Palmyra.

\begin{tabular}{|c|c|c|c|c|c|c|}
\hline Sample type & Average residue $(\mu \mathrm{g} / \mathrm{g})$ & Range & MLOD $(\mu \mathrm{g} / \mathrm{g})$ & MLOQ $(\mu \mathrm{g} / \mathrm{g})$ & \# Samples tested & \# Positive \\
\hline Mullet fish & 0.337 & $0.058-1.160$ & 0.013 & 0.042 & 24 & 24 \\
\hline Sooty tern - whole body & $<$ MLOD & $\mathrm{N} / \mathrm{A}$ & 0.007 & 0.024 & $2^{\mathrm{a}}$ & 0 \\
\hline Sooty tern - liver & $<$ MLOD & $\mathrm{N} / \mathrm{A}$ & 0.023 & 0.078 & $2^{\mathrm{a}}$ & 0 \\
\hline Red-footed booby - whole body & $<$ MLOD & $\mathrm{N} / \mathrm{A}$ & 0.007 & 0.024 & $1^{\mathrm{a}}$ & 0 \\
\hline Red-footed booby - liver & $<$ MLOD & $\mathrm{N} / \mathrm{A}$ & 0.023 & 0.078 & $1^{\mathrm{a}}$ & 0 \\
\hline Bristle-thighed curlew - whole body & 0.775 & $0.381-1.040$ & 0.007 & 0.024 & 6 & 6 \\
\hline Bristle-thighed curlew - liver & 2.240 & $1.110-10.500$ & 0.023 & 0.078 & 4 & 4 \\
\hline Ruddy turnstone - whole body & 0.381 & $0.250-0.511$ & 0.007 & 0.024 & 2 & 2 \\
\hline Ruddy turnstone - liver & 2.620 & $2.140-3.100$ & 0.023 & 0.078 & 2 & 2 \\
\hline Black noddy - whole body & $<$ MLOD & $\mathrm{N} / \mathrm{A}$ & 0.007 & 0.024 & 1 & 0 \\
\hline Black noddy - liver & $<$ MLOD & $\mathrm{N} / \mathrm{A}$ & 0.023 & 0.078 & 1 & 0 \\
\hline Pacific golden plover - whole body & 0.291 & $0.145-0.436$ & 0.007 & 0.024 & 2 & 2 \\
\hline Pacific golden plover - liver & 1.265 & $0.841-1.690$ & 0.023 & 0.078 & 2 & 2 \\
\hline Wandering tattler - whole body & 0.104 & $\mathrm{~N} / \mathrm{A}$ & 0.007 & 0.024 & 1 & 1 \\
\hline Wandering tattler - liver & 0.680 & $\mathrm{~N} / \mathrm{A}$ & 0.023 & 0.078 & 1 & 1 \\
\hline Northern pintail - whole body & $0.007^{\mathrm{b}}$ & $\mathrm{N} / \mathrm{A}$ & 0.007 & 0.024 & 1 & 1 \\
\hline Northern pintail - liver & $0.063^{\mathrm{b}}$ & $\mathrm{N} / \mathrm{A}$ & 0.023 & 0.078 & 1 & 1 \\
\hline Land crab (Cardisoma sp.) - claw meat & 0.124 & $<$ MLOD -0.280 & 0.018 & 0.061 & $6^{c}$ & 4 \\
\hline Land crab (Cardisoma sp.) - hepatopancreas & 1.583 & $<$ MLOD -5.490 & 0.018 & 0.061 & $6^{c}$ & 5 \\
\hline Land crab (Cardisoma sp.) - whole body & $<$ MLOD & $\mathrm{N} / \mathrm{A}$ & 0.018 & 0.061 & 1 & 0 \\
\hline Hermit crab & $0.968^{\mathrm{d}}$ & $0.356-1.580$ & 0.018 & 0.061 & 2 & 2 \\
\hline Fiddler crab & $<$ MLOD & $\mathrm{N} / \mathrm{A}$ & 0.018 & 0.061 & 1 & 0 \\
\hline Green Sea turtle (various tissues) & $<$ MLOD & $\mathrm{N} / \mathrm{A}$ & 0.013 & 0.042 & 1 & 0 \\
\hline Puffer fish & 0.438 & $\mathrm{~N} / \mathrm{A}$ & 0.013 & 0.042 & 1 & 0 \\
\hline Jellyfish & $<$ MLOD & $\mathrm{N} / \mathrm{A}$ & 0.013 & 0.042 & 1 & 0 \\
\hline Rat - whole body & 3.753 & $1.410-6.450$ & 0.029 & 0.096 & 21 & 21 \\
\hline Rat - liver & 18.860 & $9.570-29.000$ & 0.029 & 0.102 & 21 & 21 \\
\hline
\end{tabular}

\footnotetext{
a Deaths due to bird strike excluded from analysis.

b Value is less than MLOQ.

c Claw meat and hepatopancreas were analyzed separately from each of 6 individual crabs.

d Two extractions were performed on one sample. The higher of the two values is used in calculations.
} 
crabs. Residue levels in land crab hepatopancreas tissue $(1.583 \pm 0.903 \mu \mathrm{g} / \mathrm{g})$ were higher than claw meat $(0.123 \pm 0.052$ $\mu \mathrm{g} / \mathrm{g}$, mean $\pm \mathrm{SE}$ ). The single land crab for which whole body analysis was performed had residue levels < MLOD (Table 5).

\subsubsection{Sea turtle and jelly fish}

A green sea turtle carcass and a jellyfish were found dead during the eradication effort. A full necropsy was conducted on the sea turtle by the project veterinarian and tissue samples were analyzed for brodifacoum residues. Detectable brodifacoum residues were not found in any tissue analyzed (liver, muscle, stomach lining, or stomach contents). A whole body analysis of the jellyfish showed no detectable brodifacoum residues. Reference tissue to develop quality control was not available for either the jellyfish or sea turtle, so clean fish tissue was used in the analysis.

\subsubsection{Rats}

All dead rats collected contained quantifiable brodifacoum residues (Table 5). Average rat brodifacoum residues were $3.753 \pm 0.345 \mu \mathrm{g} / \mathrm{g}$ in carcasses and $18.860 \pm 9.570 \mu \mathrm{g} / \mathrm{g}$ in livers (mean \pm SE). The rat that was captured alive more than two weeks after the second bait drop contained higher whole body brodifacoum residues $(6.800 \mu \mathrm{g} / \mathrm{g})$ than that for all other rats that were collected dead.

\section{Discussion}

Brodifacoum residues were detected in nearly every environmental compartment analyzed. However, given the magnitude of the rodenticide bait application ( $\sim 6$ times the application rate allowed under the EPA Section 3 label), we are not surprised by these findings. In other studies with lower application rates, brodifacoum residues were detected (see below). Our data suggest that even in a short one-month period, brodifacoum residues can reach many parts of the terrestrial and marine food webs, and that residue levels begin to decline in some biological samples (Fig. 2).

Avian mortalities are often reported as a result of brodifacoum broadcasts (e.g. Eason et al., 2002; Dowding et al., 2006; Howald et al., 2009; Masuda and Jamieson, 2013). Brodifacoum is highly toxic to birds in very small doses (Godfrey, 1986). Dowding et al. (1999) provide a liver residue value threshold of $0.5 \mathrm{mg} / \mathrm{kg}$ for lethal exposure to brodifacoum in birds. Based on other research, most of the bird carcasses that were found with detectable levels of brodifacoum were likely killed by brodifacoum poisoning. A probabilistic model places the liver residue value threshold for lethal exposure even lower, at about $0.1-0.2 \mathrm{mg} / \mathrm{kg}$ for raptors (Thomas et al., 2011). The residue values for the birds on Palmyra Atoll are well above these thresholds $(0.145-10.5 \mu \mathrm{g} / \mathrm{g})$ and within

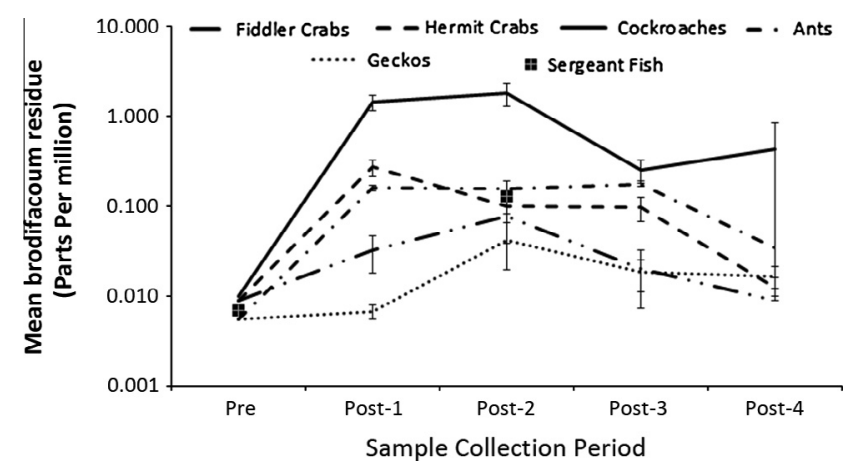

Fig. 2. Residues in biological samples over time. Mean residues were calculated using 0.5 Method Limit of Detection (MLOD) for samples with residues <MLOD and include all samples collected during systematic sampling as outlined in Table 1. the range reported for avian mortalities from other applications of brodifacoum where necropsies documented severe hemorrhaging (Ebert and Burek-Huntington, 2010; Howald et al., 1999). Secondary poisoning of shorebirds via consumption of brodifacoum is documented in the literature. Godfrey (1985) describes an incident at an aviary where a number of birds, including shorebird species (avocets and plovers), died from consumption of ants and cockroaches that had eaten brodifacoum bait applied in bait stations, resulting in avian tissue residue values that ranged from 0.081 to $1.69 \mathrm{mg} / \mathrm{kg}$. Based on a brodifacoum residue level of $0.77 \mathrm{mg} / \mathrm{kg}$ in the liver of a New Zealand dotterel, Dowding et al. (2006) concluded that the cause of death was consumption of contaminated invertebrates that had eaten aerially broadcast $20 \mathrm{ppm}$ brodifacoum bait.

Brodifacoum 25W: Conservation was available to all target and many non-target organisms, and brodifacoum residues were detected in all non-target animal groups sampled. Residues in non-target animals could have arisen from non-target organisms feeding directly on bait or they were secondary consumers feeding on organisms exposed to bait. Cockroaches, ants, fish, hermit crabs, and bristle-thighed curlews are the most-likely non-targets to have fed directly on bait because residues were detected in samples collected as early as three days after the initial bait application. Geckos, some birds, and possibly fiddler crabs may represent secondary or tertiary exposure after feeding on contaminated organisms. Foraging behavior and diet likely reduced direct exposure to bait pellets.

The Northern pintail carcass collected in February 2012 provides the most longterm evidence for brodifacoum's persistence in the atoll's ecosystem. This migratory waterfowl would likely not have been present on the atoll during the bait application in June 2011 and would not have arrived until the 2011 fall migratory period. Its exposure to brodifacoum could have occurred in another location, but if related to the bait application, would have been through chronic ingestion of contaminated invertebrates on the atoll months after the bait application. If the pintail's carcass had not been found and collected, crabs and other scavengers would have consumed the contaminated tissues and continued the cycling of brodifacoum through the food web.

Brodifacoum residues were detected in the nine soil and one freshwater sample. We were not able to detect brodifacoum residues in saltwater, which was probably the result of dilution from a large body of seawater, a relatively high flush rate through the lagoon, and the relative insolubility of brodifacoum in water (US EPA, 1998). Soil was the only environmental compartment analyzed that had detectable brodifacoum residue before bait was applied (i.e., at Pre). We believe that the two soil samples with residue levels during Pre resulted from long-term residence of residues in the soil from prior use of brodifacoum for local rat control at Palmyra. Several types of rodenticides had been used at Palmyra prior to the 2011 rat eradication operation. Although brodifacoum was used on Palmyra in 2004 (W. Pitt, pers. obs.), the most recent time prior to 2011 is unknown. Brodifacoum is not water soluble, and 5-day rainfall trials have shown that this toxicant does not easily break down or leach to or from the soil (Booth et al., 1999). Such immobility of brodifacoum from bait pellets to soil may in part explain the relatively low proportion (33\%) of soil samples contaminated with brodifacoum following the 2011 bait application, as well as long-term persistence of the residues as evidenced by the two soil samples collected prior to the 2011 bait application.

The pathway for residues contained in bird strike mortalities is unclear. One red-footed booby that died after colliding with the helicopter had detectable whole-body residues, but no residues were in the liver. If the bird ingested bait or other animals with residues, we would expect brodifacoum residues in the bird's liver in 
addition to the whole-body residues. This bird carcass was recovered during the second bait application. The residues in this carcass may have been the result of contamination because most birdstrike mortalities had injuries that compromised the integrity of the skin (e.g., missing wings). The second confirmed bird strike with whole-body brodifacoum residues was a sooty tern, which had extensive internal injuries (the liver could not be recovered) and the carcass was found in the helicopter bait hopper which could lead to further contamination of the specimen.

The number of non-target mortalities resulting from this eradication attempt cannot be determined solely by the number of non-target organisms collected because some non-target mortalities probably went undiscovered. Although USFWS (2011) estimated that more than 20,000 rats were killed during the eradication, only a few dozen rats were found during the project. A more conservative estimate of bird mortality would be based on the island wide low tide survey of shorebirds (USFWS, unpubl. data). One of the primary reasons for conducting the operation in June was to have disturbance coincide with low bird numbers and at a time when fluctuation in bird populations would be lowest. We can estimate the maximum number of birds that could have died from the operation by using the low tide survey counts conducted prior to the operation (3 June 2011) and comparing these counts to the numbers after the operation but prior to the arrival of birds in autumn (30 July 2011) (Fig. 3). An additional 12 bristle-thighed curlews were held in captivity during the operation. Thus, we estimate that the maximum number of birds that could have died during the operation were 68 bristle-thighed curlews, 28 Pacific golden plovers, 10 wandering tattlers, and 8 ruddy turnstones. These estimated bird losses are well below the numbers permitted to be taken (USFWS Migratory Bird Permit MB 44187A-0). Additionally, many birds remained alive on the atoll well after bait broadcast, which suggests that not all birds were affected equally by the operation.

Furthermore, the lack of dead organisms before the initial bait broadcast and the lack of brodifacoum residues in the non-target organisms available and sampled prior to the initial bait broadcast, compared to the frequent detection of residues in non-targets after the baiting began suggests that brodifacoum probably played a role in the death of some if not most of the non-target animals that were found dead during and after the operation. Dowding et al. (2006) reported mortality of 50-60\% of the New Zealand dotterels over a 3 month period following the aerial broadcast of brodifacoum bait, based on carcasses found and the disappearance of banded birds, compared to the normal mortality rate of $6-9 \%$ per

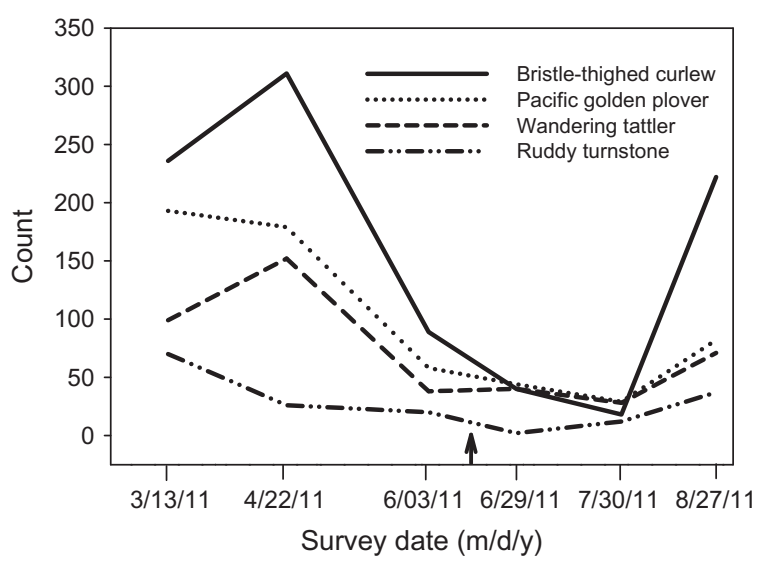

Fig. 3. Low tide shorebird survey results for the six dates, pre- and post-rat eradication attempt, Palmyra, tropical Pacific. The arrow indicates the beginning of the rodenticide bait application (June 12, 2011). Source USFWS (2011). year for that population. This unusually high mortality rate, and the liver residues of brodifacoum detected in a dotterel and pied stilt, led them to conclude that the brodifacoum broadcast was the cause. Aside from the bird deaths resulting from collision with the helicopter, and the green sea turtle, all other vertebrates collected opportunistically (i.e., fish and birds) had detectable levels of brodifacoum residues (Table 5; Pitt et al., 2012).

Based on the Environmental Impact Statement (EIS), we expected that some bird death would result from the planned brodifacoum application to Palmyra. However, the EIS did not predict mullet or land crab mortality (USFWS, 2011). Although dead land crabs were found to contain brodifacoum residues, a study on a similar species showed that brodifacoum is not toxic to land crabs under similar conditions (Pain et al., 2000). Brodifacoum residues detected in fish confirmed that the rodenticide moved into the marine system, probably via bait drift off the flight line due to windy conditions, and such exposure needs to be considered and evaluated in future operations. Bait drift density in the marine environment was variable from $0.0 \mathrm{~kg} / \mathrm{ha}$ to $46.3 \mathrm{~kg} / \mathrm{ha}$ ( mean $=17.1 \mathrm{~kg} / \mathrm{ha}$ ) (Engeman et al., 2013), and was directly available to a wide variety of marine organisms. All 21 groups of dead mullet that we collected contained detectable brodifacoum residues. Mullet range widely in the Palmyra lagoon environment and are fed upon by a wide variety of predatory fish (e.g., bluefin trevally (Caranx melampygus) and giant trevally (C. ignobilis), blacktip reef sharks (Carcharhinus melanopterus), and barracuda (Sphyraena barracuda)), and potentially seabirds, such as brown noddies (Anous stolidus) (Ashmole, 1967; Vidal-Martínez et al., 2012; J. McLaughlin unpubl. data). Therefore, having all sampled mullet contaminated with brodifacoum, and their status as a common prey item, reveals the high probability that such a terrestrial operation of attempted rat eradication can have bottom up effects in tropical marine food webs (Ebbert and Burek-Huntington, 2010). Thus, the exposure risk to other marine organisms and indirect effects to birds should be considered in future applications. In addition, accumulation of residues in reef fish and potentially predatory fish could pose an exposure risk to fishermen in waters near eradication projects.

The collection of all non-target organisms for residue analysis largely ceased after the initial monitoring crew had departed the island (first week in July 2011). The lack of carcasses discovered after this time was either because no further non-target mortality occurred after this date, carcasses were missed because of the difficulty observing carcasses combined with the rapid carcass removal by scavengers, and/or a reduction in on-island activity by remaining island inhabitants, including carcass search activities. USFWS personnel monitoring shorebird roost sites searched for dead or poisoned birds daily until August 4. In addition, other personnel (IC, USFWS, and others) searched for dead birds during roost counts and other activities through September. However, directed searches for all non-target animals other than birds ceased after the monitoring crew left the atoll. Brodifacoum residues were still detected in the terrestrial and marine environments through August 2011. Thus, the lack of any non-target mortalities later in the year may have been a result of the reduced search effort.

Comparing the results of residues collected in this study to other studies is difficult due to differences in rodenticides used, methodology, and application rates. However, four major projects have been completed recently in the United States using similar broadcast techniques but at a lower rate. One project on Rat Island (Alaska) used Brodifacoum 25D: Conservation at a rate of $17 \mathrm{~kg} / \mathrm{ha}$ (2 applications), two projects on Mokapu and Lehua Islands (Hawaii) used Diphacinone 50: Conservation at a rate of $13.8 \mathrm{~kg} /$ ha (2 applications), and a fourth project on Cocos Island (Marianas) used two Diphacinone 50: Conservation hand broadcasts at a rate 
of $12.98 \mathrm{~kg} /$ ha during the first application and $10.36 \mathrm{~kg} / \mathrm{ha}$ during the second ( 7 days later), and a commensal brodifacoum product was used in bait stations in the resort area. On Mokapu Island, diphacinone residues were not detected in sea water, fish, or invertebrate samples (limpets), and non-target carcasses were not found (Gale et al., 2008). On Lehua Island, diphacinone residues were not detected in sea water, soil, fish, invertebrate, or crab samples, and non-target carcasses were not found (Orazio et al., 2009). However, it must be noted that diphacinone is a first generation anticoagulant with lower toxicity and persistence than brodifacoum, which could explain the lack of residues on Mokapu and Lehua. Lujan et al. (2010) reported that on Cocos Island, hermit crabs were sampled 7, 30, 60, and 90 days post-bait application. Brodifacoum residues were detected in one of 12 hermit crab samples, and diphacinone residues were not detected in any of the 12 hermit crabs. Brodifacoum and diphacinone residues were detected in three land crabs that were collected 7 days after bait was applied (brodifacoum in one of three samples and diphacinone in all three samples). Diphacinone and brodifacoum residues were not detected in any of the 12 soil samples, but diphacinone residues were detected in one of 12 water samples $(0.055 \mathrm{ng} / \mathrm{ml})$, which was a fresh water sample (USDA unpubl data). No non-target animals were collected after the eradication with systematic searches ( $54 \mathrm{~h}$ over 36 hectares) and long-term opportunistic searches. On Rat Island, monitoring was limited to the collection of water samples collected within $48 \mathrm{~h}$ of aerial broadcast of bait (Buckelew et al., 2009). Brodifacoum residues were not detected in any of 18 marine water samples, yet all of the marine water samples were collected from a single location on the island (Gunner's Cove). Brodifacoum residues were detected in two of 10 freshwater samples collected from two lakes. No additional monitoring occurred after the broadcast because winter weather excluded crews from the island. The next spring, 423 dead birds of 26 species were collected including 320 glacous-winged gulls (Larus bachmani) and 46 bald eagles (Haliaeetus leucocephalus) (Ebbert and Burek-Huntington, 2010). Of the 36 bird carcasses from nine species tested for residues, 35 carcasses had detectable brodifacoum residues. Brodifacoum residues in liver tissue samples from bird carcasses ranged from 0.027 to $4.189 \mu \mathrm{g} / \mathrm{g}$, which were similar to the levels of brodifacoum residues from bird carcasses collected during our study at Palmyra despite the higher application on Palmyra. There is reason to be concerned that Palmyra may have suffered higher mortality than we documented in our short-term assessment because residues persisted and all carcasses were almost certainly not discovered.

\section{Conclusions}

Primary, secondary, tertiary and even further long term exposure of both terrestrial and aquatic organisms that are contaminated with the toxicant should be considered in all eradication operations, and therefore an understanding of the local food web is essential prior to broadcasting toxic bait. Brodifacoum residues in ants, cockroaches, and geckos did not appear to be a significant concern for secondary consumption on Palmyra because of the lack of sensitive secondary consumers (i.e., mammals or insectivorous birds). However, other island ecosystems may have a more abundant and diverse secondary fauna and future eradication efforts in island ecosystems should consider non-target exposure to toxicants through consumption of contaminated invertebrates in their risk assessments (Masuda et al., 2014). In the case of Palmyra, it was expected that terrestrial crabs would be at risk of primary exposure to bait pellets on land and through secondary pathways by foraging on the carcasses of rats and other organisms with brodifacoum residues. Our results suggest that organisms like the gecko, which were considered to be at a low risk of mortality, were exposed to brodifacoum probably as a result of feeding on invertebrates (i.e., cockroaches, ants, and other insects) which contained brodifacoum residues and potentially bait pellets (Hoare and Hare, 2006). Our data were not collected in a way to allow definitive statements about potential secondary exposure. The confirmed death of 47 mullets coincidental to the eradication and subsequent determination that all samples contained brodifacoum residues demonstrates that the marine environment experiences a greater risk of brodifacoum exposure than previously thought and this monitoring effort was the most comprehensive post-baiting monitoring for environmental residues that has been undertaken and reported to date. Mullet are common prey species of many aquatic and terrestrial predatory species. It is likely that the brodifacoum residues in mullet would be transferred to predators upon consumption. Brodifacoum resides were still being found in biological samples collected up to 11 weeks following the first bait application (Fig. 2). Future projects should include monitoring for toxicant residues in fish, insects, crabs, and other organisms for at least 180 days following rodenticide broadcast if the persistence of residues is to be more accurately determined. Due to the short duration of monitoring in our project, we were unable to record residues consistently below MLOD. Residues in non-target organisms may have persisted until February 2012, 7 months after the first bait application. Thus, the risk of exposure to other organisms may persist for many months following application of brodifacoum bait.

Rat eradications that use brodifacoum bait must balance the risk of non-target mortalities and prolonged residues in the terrestrial and aquatic environment with the likelihood and benefits of removal of the target invasive rat species. While some conservationists have suggested that most non-target impacts from rat eradications are largely ephemeral, and that the conservation benefits of having a rat free island outweigh the costs of individual non-target mortalities (e.g., Howald et al., 2009), long term monitoring of affected species should be conducted to confirm this assumption. The very large amount of brodifacoum deposited on Palmyra as part of the rat eradication operation was unprecedented. However, some future rodent eradication operations on islands could consider applying similar amounts of brodifacoum due to changing best practices, such as those outlined by Pott et al. (2015) and Keitt et al. (2015). Although we realize that some negative impacts to non-targets are inevitable in most rateradication operations, we suggest that future research prioritizes methods to limit non-target consumption of bait, and that minimizes the amount of toxicant bait applied.

\section{Acknowledgments}

The authors wish to thank T. McAuliffe (USDA), K. Hayes (USDA), A. Meyer (USFWS), S. Hathaway (USGS) and A. Kristof (USFWS) for exceptional assistance in the field. We thank D. Griffin and D. Goldade for assistance with residue analysis and B. Kimball for editorial suggestions. This study was funded by IC, USFWS, TNC, and USDA. Author contributions: WCP and ARB conceptualized the project, collected, analyzed, and interpreted data, and wrote the paper; ABS wrote the paper; SFV collected data; JDE conceptualized the project. ASW and GRH assisted in the project design.

\section{Appendix A. Supplementary material}

Supplementary data associated with this article can be found, in the online version, at http://dx.doi.org/10.1016/j.biocon.2015.01. 008. 


\section{References}

Angel, A., Wanless, R.M., Cooper, J., 2009. Review of impacts of the introduced house mouse on islands in the Southern Ocean: are mice equivalent to rats? Biol. Invasions $11,1743-1754$.

Ashmole, M.J., 1967. Comparative Feeding Ecology of Sea Birds of a Tropical Oceanic Island, vol. 24. Peabody Museum, Yale University, Bulletin, 131 pp.

Banks, P.B., Hughes, N.K., 2012. A review of the evidence for potential impacts of black rats (Rattus rattus) on wildlife and humans in Australia. Wildlife Res. 39, 78-88.

Berentsen, A.R., Pitt, W.C., Eisemann, J.D., Engeman, R.M., 2014. Longevity of rodenticide bait pellets in a tropical environment following a rat eradication program. Environ. Sci. Pollut. Res. 21, 2283-2288.

Booth, L.H., Ogilvie, S.C., Eason, C.T., 1999. Persistence of sodium monofluoroacetate (1080), pindone, cholecaliferol, and brodifacoum in possum baits under simulated rainfall. NZ J. Agric. Res. 42, 107-112.

Buckelew, S., Howald, G., MacLean, S., Byrd, V., Daniel, L., Ebbert, S., Meeks W., 2009. Rat Island Habitat Restoration Project: Operational Report. Report to USFWS. Island Conservation, Santa Cruz.

Caut, S., Angulo, E., Courchamp, F., 2008. Dietary shifts of an invasive predator: rats, seabirds and turtles. J. Appl. Ecol. 45, 428-437.

Clark, D.A., 1981. Foraging patterns of black rats across a desert-montane forest gradient in the Galápagos Islands. Biotropica 13, 182-194.

Dowding, J.E., Murphy, E.C., Veitch, C.R., 1999. Brodifacoum residues in target and non-target species following an aerial poisoning operation on Motuihe Island, Hauraki Gulf, New Zealand. NZ J. Ecol. 23, 207-214.

Dowding, J.E., Lovegrove, T.G., Ritchie, J., Kast, S.N., Puckett, M., 2006. Mortality of northern New Zealand dotterels (Charadrius obscurus aquilonius) following an aerial poisoning operation. Notornis 53, 235-239.

Dunlevy, P., Swift, C.E., 2010. Nontarget risk and environmental fate of the broadcast application of a diphacinone rodenticide at Mōkapu and Lehua Islands, Hawai'i. Proc. Vert. Pest Conf. 24, 140-145.

Eason, C.T., Murphy, E.C., Wright, G.R.G., Spurr, E.B., 2002. Assessment of risks of brodifacoum to non-target birds and mammals in New Zealand. Ecotoxicology $11,35-48$.

Ebbert, S., Burek-Huntington, K., 2010. Anticoagulant residual concentration and poisoning in birds following a large-scale aerial broadcast of 25-ppm brodifacoum bait for rat eradication on Rat Island, Alaska. Proc. Vert. Pest Conf. 24, 153-160.

Engeman, R.M., Pitt, W.C., Berentsen, A.R., Eisemann, J.D., 2013. Assessing density and distribution of aerially broadcast toxic bait under difficult field circumstances during a rat eradication effort on Palmyra Atoll. Environ. Sci. Pollut. Res. 20, 480-487.

Fall, M.W., Medina, A.B., Jackson, W.B., 1971. Feeding patterns of Rattus rattus and Rattus exulans on Eniwetok Atoll, Marshall Islands. J. Mammal. 51, 69-76.

Gale, R.W., Tanner, M., Orazio, C.E., 2008, Determination of Diphacinone in Sea Water, Vertebrates, Invertebrates, and Bait Pellet Formulations Following Aerial Broadcast on Mokapu Island, Molokai, Hawai'i. U.S. Geological Survey Open-File Report 2008-1285, 16 pp.

Godfrey, M.E.R., 1985. Non-target and secondary poisoning hazards of 'second generation' anticoagulants. Acta Zool. Fennici 173, 209-212.

Godfrey, M.E.R., 1986. An Evaluation of the Acute Oral Toxicity of Brodifacoum to Birds. In: Proc 12th Vertebr Pest Conf. 1986, pp. 78-81.

Grant-Hoffman, M.N., Barboza, P.S., 2010. Herbivory in invasive rats: criteria for food selection. Biol. Invasions 12, 805-825.

Hoare, J.M., Hare, K.M., 2006. Hoplodactylus maculatus (common gecko) toxin consumption. Herp. Rev. 36, 86-87.

Howald, G.R., Mineau, P., Elliott, J.E., Cheng, K.M., 1999. Brodifacoum poisoning of avian scavengers during rat control on a seabird colony. Ecotoxicology 8, 431447.

Howald, G., Donlan, C.J., Galvan, J.P., Russell, J.C., Parkes, J., Samaniego, A., Wang, Y., Veitch, D., Genovesi, P., Pascal, M., Saunders, A., Tershy, B., 2007. Invasive rodent eradication on islands. Conserv. Biol. 21, 1258-1268.

Howald, G., Donlan, C.J., Faukner, K.R., Ortega, S., Gellerman, H., Croll, D.A., Tershy, B.R., 2009. Eradication of black rats Rattus rattus from Anacapa Island. Oryx 44, 30-40.

Keitt, B., Griffiths, R., Boudjelas, S., Broome, K., Cranwell, S., Millett, J., Pitt, W., Samaniego-Herrera, A., 2015. Best practice guidelines for rat eradication on tropical islands. Biol. Conserv. 185, 17-26.

Lujan, D.T., Vice, D.S., Guerrero, J.P., Candaso, C.F., 2010. Rodent eradication on Cocos Island, Guam: integrating wildlife damage management, resort operations, and non-target concerns. Proc. Vert. Pest Conf. 24, 9-13.

Masuda, B.M., Jamieson, I.G., 2013. Response of a reintroduced bird population to a rat reinvasion and eradication. NZ J. Ecol. 37, 224-231.

Masuda, B.M., Fisher, P., Jamieson, I.G., 2014. Anti-coagulant rodenticide brodifacoum detected in dead nestlings of an insectivorous passerine. NZ J. Ecol. 38, 110-115.

Ogilvie, S.C., Pierce, R.J., Wright, G.R.G., Booth, L.H., Eason, C.T., 1997. Brodifacoum residue analysis in water, soil, invertebrates, and birds after rat eradication on Lady Alice Island. NZ J. Ecol. 21, 195-197.

Orazio, C.E., Tanner, M.J., Swenson, C., Herod, J., Dunlevy, P., Gale G.W., 2009. Results of Laboratory Testing for Diphacinone in Seawater, Fish, Invertebrates, and Soil
Following Aerial Application of Rodenticide on Lehua Island, Kauai County, Hawaii. U.S. Geological Survey Open-File Report 2009-1142, 15 pp. with appendix.

Pain, D.J., Brooke, M.de L., Finnie, J.K., Jackson, A., 2000. Effects of brodifacoum on the land crab of Ascension Island. J. Wildlife Manage. 64, 380-387.

Parkes, J., Fisher, P., Forrester, G., 2011. Diagnosing the cause of failure to eradicate introduced rodents on islands: brodifacoum versus diphacinone and method of bait delivery. Cons. Evidence 8, 100-106.

Pitt, W.C., Eisemann, J.D., Swift, C.E., Sugihara, R.T., Dengler-Germain, B., Driscoll, L., 2005. Diphacinone Residues in Free-Ranging Wild Pigs Following Aerial Broadcast of a Rodenticide Bait in a Hawaiian forest. QA-1077 Final Report USDA/APHIS/WS/NWRC. Hilo, Hawaii, 35 pp.

Pitt, W.C., Driscoll, L.C., Sugihara, R.T., 2011. Efficacy of rodenticide baits for the control of three invasive rodent species in Hawaii. Arch. Environ. Contam. Toxicol. 60, 533-542.

Pitt, W.C., Berentsen, A.R., Volker, S.F., Eisemann, J.D., 2012. Palmyra Atoll Rainforest Restoration Project: Monitoring Results for the Application of Broadcast of Brodifacoum 25W: Conservation to Eradicate Rats. QA-1875 Final Report. USDA/APHIS/WS/NWRC. Hilo, Hawaii, 85 pp.

Pott, M., Wegmann, A.S., Griffiths, R., Samaniego-Herrera, A., Cuthbert, R.J., Brooke, M.D.L., Pitt, W.C., Berentsen, A.R., Holmes, N.D., Howald, G.R., Ramos-Rendón, K., Russell, J.C., 2015. Improving the odds: assessing bait availability before rodent eradications to aid in selecting bait application rates. Biol. Conserv. 185, 27-35.

Primus, T.M., Graves, S.F., 2006. USDA National Wildlife Research Center Method 139A: Determination of Brodifacoum in Hermit and Land Crab Tissue. Unpublished report. $16 \mathrm{pp}$.

Primus, T.M., Wright, G., Fisher, P., 2005. Accidental discharge of brodifacoum baits in a tidal marine environment: a case study. Bull. Environ. Contam. Toxicol. 74, 913-919.

Primus, T.M., Kohler, D.J., Johnston, J.J., Sugihara, R.T., Pitt, W.C., 2006 Determination of diphacinone residues in Hawaiian invertebrates. J. Chromatogr. Sci. 44, 1-5.

Ruffino, L., Bourgeois, K., Vidal, E., Duhem, C., Paracuellos, M., Escribano, F., Sposimo, P., Baccetti, N., Pascal, M., Oro, D., 2009. Invasive rats and seabirds after 2000 years of an unwanted coexistence on Mediterranean islands. Biol. Invasions 11, 1631-1651.

Shiels, A.B., Drake, D.R., 2011. Are introduced rats (Rattus rattus) both seed predators and dispersers in Hawaii? Biol. Invasions 13, 883-894.

Shiels, A.B., Flores, C.A., Khamsing, A., Krushelnycky, P.D., Mosher, S.M., Drake, D.R., 2013. Dietary niche differentiation among three species of invasive rodents (Rattus rattus, $R$. exulans, Mus musculus). Biol. Invasions 15, 1037 1048.

Shiels, A.B., Pitt, W.C., Sugihara, R.T., Witmer, G.W., 2014. Biology and impacts of Pacific island invasive species. 11. Rattus rattus, the black rat (Rodentia: Muridae). Pac. Sci. 68, 145-184.

St Clair, J.J.H., 2011. The impacts of invasive rodents on island invertebrates. Biol. Conserv. 144, 68-81.

Sweetapple, P.J., Nugent, G., 2007. Ship rat demography and diet following possum control in a mixed podocarp-hardwood forest. NZ J. Ecol. 31, 186201.

Thomas, P.J., Mineau, P., Shore, R.F., Champoux, L., Martin, P.A., Wilson, L.K., Fitzgerald, G., Elliott, J.E., 2011. Second generation anticoagulant rodenticides in predatory birds: probabilistic characterisation of toxic liver concentrations and implications for predatory bird populations in Canada. Environ. Int. 37, 914920.

Towns, D.R., 2009. Rodents. In: Gillespie, R.G., Clague, D.A. (Eds.), Encyclopedia of Islands. University of California Press, Berkeley, pp. 792-796.

Towns, D.R., Atkinson, I.A.E., Daugherty, C.H., 2006. Have the harmful effects of introduced rats on islands been exaggerated? Biol. Invasions 8, 863-891.

Traveset, A., Nogales, M., Alcover, J.A., Delgado, J.D., Lopez-Darias, M., Godoy, D. Igual, J.M., Bover, P., 2009. A review of the effects of alien rodents in the Balearic (Western Mediterranean Sea) and Canary Islands (Eastern Atlantic Ocean). Biol. Invasions 11, 1653-1670.

US EPA, 1998. United States Environmental Protection Agency, Reregistration Eligibility Decision (RED) Rodenticide Cluster. Prevention, Pesticides and Toxic Substances (7508W). EPA 738-R-98-007.

USFWS, 2011. Palmyra Atoll National Wildlife Refuge Rat Eradication Project Final Environmental Impact Statement. U.S. Fish and Wildlife Service report, Portland, Oregon. 210 pp.

Vidal-Martínez, V.M., Aguirre-Macedo, M.L., McLaughlin, J.P., Hechinger, R.F., Jaramillo, A.G., Shaw, J.C., James, A.K., Kuris, A.M., Lafferty, K.D., 2012. Digenean metacercariae of fishes from the lagoon flats of Palmyra Atoll, Eastern Indo-Pacific. J. Helminthol. 5, 1-17.

Wegmann, A., Flint, E., White, S., Fox, M., Howald, G., McClelland, P., Alifano, A. Griffiths, R., 2012. Pushing the envelope in paradise: a novel approach to rat eradication at Palmyra Atoll. Proc. Vert. Pest. Conf. 25, 48-53.

Wester, L., 1985. Checklist of the vascular plants of the Northern Line Islands. Atoll Res. Bull. 287, 1-38.

Witmer, G.W., Pierce, J., Pitt, W.C., 2011. Eradication of invasive rodents on islands of the United States. In: Veitch, C.R., Clout, M.N., Towns, D.R. (Eds.), Island Invasives: Eradication and Management. IUCN, Gland, pp. 135-138. 